\title{
Should All Scorpion Stings be Followed Up in the Intensive Care
} Unit?

\author{
Ayşe Şahin Tutak ${ }^{1 *}$, Meral Çeliker ${ }^{1}$, Hüseyin Avni Fındıklı ${ }^{1}$ Bülent Karakaya ${ }^{1}$, Atilla \\ Tutak² $^{2}$ Öznur Uluada $\breve{g}^{2}$ \\ ${ }^{1}$ Department of İnternal Medicine, Adıyaman University of Medical Faculty, Adıyaman, Turkey \\ ${ }^{2}$ Department of Anesthesia and Reanimation, Adıyaman University of Medical Faculty, Adıyaman, Turkey
}

Corresponding Author: Ayşe Şahin Tutak, Department of İnternal Medicine, Adıyaman University of Medical Faculty, Adiyaman, Turkey, Tel: + 904162161015; Fax: +904162161015; E-Mail: aysesahintutak@hotmail.com

Received: 17 January 2018; Accepted: 27 January 2018; Published: 30 January 2018

\begin{abstract}
Aim: In Turkey, as throughout the world, the incidence of scorpion sting cases and the wide-ranging clinical table, extending from local symptoms to death have not been previously estimated. Therefore, through an examination of patients followed up in the Intensive Care Unit (ICU) and the complications, the aim of this study was to evaluate the indications for acceptance of these cases into ICU.
\end{abstract}

Method: A retrospective examination was made of 59 patients admitted to the ICU of Adiyaman Training and Research Hospital because of a scorpion sting between 2013 and 2016.

Results: All the patients had a unilateral extremity sting, presented at the Emergency Department within 8 hours and were administered anti-venom. In respect of local or systemic complications, thrombus developed in the proximal of the extremity in only 2 patients. With the exception of these 2 patients, all the other cases were discharged within 2 days without complications.

Conclusion: Although the most poisonous scorpion in the world can be found in our region, no case admitted to the ICU in this 3-year period experienced any systemic complications. This is thought to be due to the early presentation at ED within the first 8 hours and that antivenom is produced in our region. In conclusion from this study, it can be recommended that patients with no requirement for the equipment of ICU should not be admitted and patients with local symptoms only should be monitored on the ward. 
Keywords: Scorpion stings; Intensive care unit

\section{Introduction}

Scorpions generally inhabit tropical and subtropical climates, living in particular in forested regions, deserts, and stony, rocky regions. Although more than 1500 scorpion species have been identified throughout the world, only about 30 of these are poisonous. Cases of scorpion poisoning in Turkey are seen most often in the South-east Anatolian region [1]. The most poisonous scorpion in the world, the Leiurus quinquestriatus has been determined in the province of Adiyaman and surrounding areas in South-east Anatolia [2]. Furthermore, the poisonous Mesobuthus nigrocinctus (black spotted yellow scorpion) was identified for the first time in the world in Adiyaman and inhabits the area surrounding Mount Nemrut (Ehrenberg 1828, Crucitti \& Vignoli 2002).

Although the frequency of scorpion stings remains high, cases of death have rarely been reported [3]. The development of severe toxicity in adults is at the rate of $0.9 \%$ [4]. When cases of scorpion sting present at the Emergency Dept, the symptoms are carefully evaluated, the necessary supportive treatments are given, and in the monitoring of symptoms, follow-up can be monitoring in the ED and when necessary transfer can be made to ICU. Therefore, the aim of this study was to evaluate patients followed up in ICU for a scorpion bite in respect of the indications for admittance to ICU and complications which developed.

\section{Materials and methods}

A retrospective examination was made of 59 patients admitted to the ICU of Adiyaman Training and Research Hospital between 2013 and 2016 because of scorpion sting and local symptoms. Data were retrieved from the electronic records system and patient files and the patients were evaluated in respect of age, gender, hematological and biochemical values.

\subsection{Statistical Analysis}

The analyses of the variables were applied using SPSS 22.0 (IBM Corp. Armonk, NY, USA) and PASS 3 (Hammer, $\varnothing$, Harper D.A.T, Ryan P.D. 2001. Paleontological statistics) software. The conformity to the normal distribution of single variable data was evaluated with the Shapiro Wilk test and of multiple variables with the Mardia test (Dornik and Hansen omnibus) and variance homogeneity with the Levene test. In the comparison of quantitative data of independent groups, the Independent -Samples t-test was used together with Bootstrap results and the MannWhitney U (Exact) test with Monte Carlo results. For the comparison of 2 repeated measurements of dependent quantitative variables, the Wilcoxon Signed Ranks test was used with Monte Carlo simulation results and to examine the interaction according to the groups of repeated measurements of the variables, the General Linear Model-Repeated Anova test was used. After controlling the age and gender factors of the variables, the Partial Correlation test was used to examine the correlations between the variables. Quantitative variables are stated in the tables as mean \pm standard deviation (SD) and range (minimum-maximum). Categorical variables are shown as 
number (n) and percentage (\%). The variables were examined at a confidence interval (CI) of $95 \%$ and a value of $\mathrm{p}<0.05$ was accepted as statistically significant.

\section{Results}

No statistically significant difference was determined between the patients accepted into ICU in this study in respect of age and gender (Table 1). A difference was found between the genders in respect of the change in the albumin values on the 1 st and $2^{\text {nd }}$ day of admittance to ICU. Significant differences were also determined by the hemoglobin and hematocrit values on the $1^{\text {st }}$ and $2^{\text {nd }}$ days (Figure 1). No statistically significant difference was determined by thrombocyte and RDW values (Table 2).

\begin{tabular}{|l|l|l|}
\hline \multirow{2}{*}{ Gender } & \multicolumn{2}{|l|}{ Age } \\
\cline { 2 - 3 } Female & Mean \pm SD. & Max.-Min. \\
\hline & $41.5 \pm 19.3$ & $87-17$ \\
\hline Male & $46.5 \pm 20.6$ & $83-18$ \\
\hline Total & $44.2 \pm 20.1$ & $87-17$ \\
\hline P Value & $\mathbf{0 . 0 0 2}$ & \\
\hline
\end{tabular}

Independent t Test (Bootstrap) - Mann Whitney U Test (Monte Carlo) -

SD: Standard Deviation - Max.: Maximum - Min.:Minumum

Table 1: Age and Gender Distribution

\begin{tabular}{|c|c|c|c|c|c|}
\hline & & Female & Male & Total & \\
\hline & & $(n=27)$ & $(n=32)$ & $(\mathrm{N}=59)$ & \\
\hline & & Mean \pm SD. & Mean \pm SD. & Mean \pm SD. & \\
\hline Albumi & & & & & \\
\hline & $1^{\text {st }}$ day & $3.86 \pm 0.53$ & $3.96 \pm 0.57$ & $3.89 \pm 0.55$ & 0.182 \\
\hline & $2^{\text {nd }}$ day & $3.44 \pm 0.58$ & $3.52 \pm 0.62$ & $3.48 \pm 0.60$ & 0.839 \\
\hline & $\mathrm{D}(1-2)$ & $0.35 \pm 0.65$ & $0.46 \pm 0.42$ & $0.41 \pm 0.53$ & $<0.001$ \\
\hline P Value & & 0.028 & $<0.001$ & $<0.001$ & \\
\hline HGB & & & & & \\
\hline & $1^{\text {st }}$ day & $13.31 \pm 1.28$ & $15.00 \pm 1.32$ & $14.18 \pm 1.51$ & $<0.001$ \\
\hline & $2^{\text {nd }}$ day & $12.26 \pm 1.69$ & $13.74 \pm 1.92$ & $13.10 \pm 1.95$ & 0.006 \\
\hline & $\mathrm{D}(1-2)$ & $1.05 \pm 1.92$ & $1.26 \pm 1.79$ & $1.17 \pm 1.83$ & $<0.001$ \\
\hline P Value & & 0.018 & 0.001 & $<0.001$ & \\
\hline RDW & & & & & \\
\hline
\end{tabular}




\begin{tabular}{|c|c|c|c|c|c|}
\hline & $1^{\text {st }}$ day & $12.55 \pm 1.23$ & $12.65 \pm 0.83$ & $12.60 \pm 1.01$ & 0.555 \\
\hline & $2^{\text {nd }}$ day & $12.73 \pm 1.29$ & $13.01 \pm 0.98$ & $12.89 \pm 1.12$ & 0.408 \\
\hline & $\mathrm{D}(1-2)$ & $-0.19 \pm 0.47$ & $-0.36 \pm 0.79$ & $-0.28 \pm 0.67$ & \begin{tabular}{|l|l|}
0.004 \\
\end{tabular} \\
\hline \multicolumn{2}{|l|}{ P Value } & 0.079 & 0.021 & 0.004 & \\
\hline \multicolumn{6}{|l|}{ PLT } \\
\hline & $1^{\text {st }}$ day & $\begin{array}{l}224.221,8 \pm 70.610 \\
5\end{array}$ & $\begin{array}{ll}218.824, & 8 \pm 68774, \\
4\end{array}$ & $\begin{array}{l}221.152,94 \pm 68.920, \\
89\end{array}$ & 0.575 \\
\hline & $2^{\text {nd }}$ day & $\begin{array}{l}215.024,5 \pm 69.281, \\
5\end{array}$ & $\begin{array}{l}187.744,8 \pm 53.952, \\
6\end{array}$ & $\begin{array}{l}199.512,55 \pm 61.905, \\
26\end{array}$ & 0.120 \\
\hline & $\mathrm{D}(1-2)$ & $9.197,3 \pm 44.049,7$ & $31.080,0 \pm 46.395,2$ & $21.640,4 \pm 46.262,03$ & 0.002 \\
\hline \multicolumn{2}{|l|}{ P Value } & 0.339 & 0.001 & 0.002 & \\
\hline \multicolumn{6}{|l|}{ HCT } \\
\hline & $1^{\text {st }}$ day & $39.4(49-34.3)$ & $44.05(51.72-34.5)$ & $42.5(51.72-34.3)$ & $<\mathbf{0 . 0 0 1}$ \\
\hline & $2^{\text {nd }}$ day & $37.4(46.34-23.5)$ & $42.3(48.87-25.6)$ & $39.3(48.87-23.5)$ & 0.001 \\
\hline & $\mathrm{D}(1-2)$ & $1.85(19.5--2.71)$ & $1.7(18.9--3.67)$ & $1.7(19.5--3.67)$ & 0.732 \\
\hline \multicolumn{2}{|l|}{ P Value } & 0.011 & 0.007 & $<0.001$ & \\
\hline
\end{tabular}

General Linear Model Repeated Anova (Wilks' Lambda) - Mann Whitney U Test (Monte Carlo) - Wilcoxon Signed Ranks Test (Monte Carlo)

SD. Standard Deviation - Max.:Maximum - Max.:Maximum

D (1-2): Differences between $1^{\text {st }}$ and $2^{\text {nd }}$ days

Table 2: Comparison of some laboratory values of the patients on the 1 st and 2nd days.

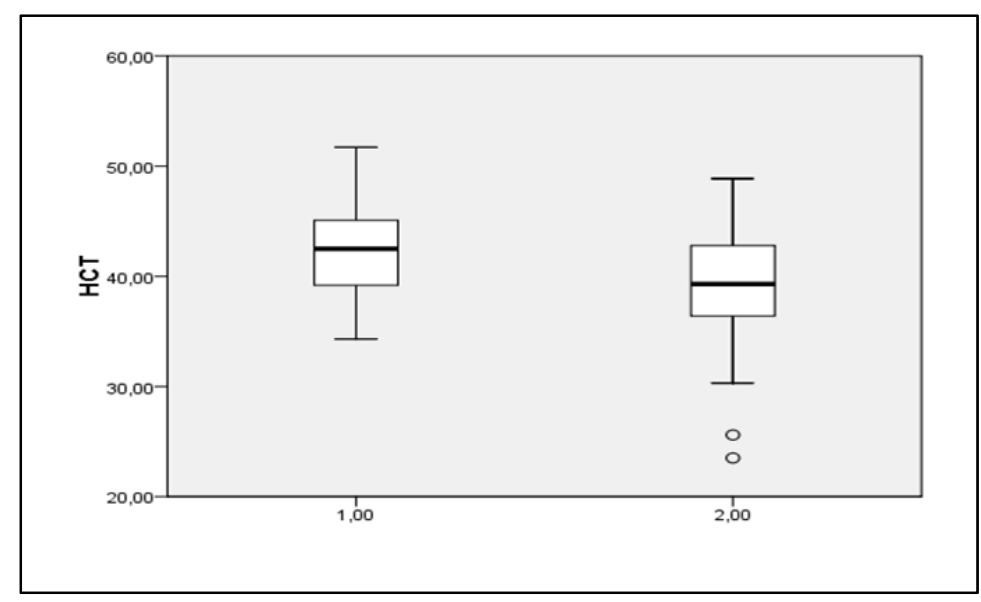

Figure 1: Evaluation of the change in total hematocrit at first and second days 
All the patients in the study had been stung once in the extremity. All the patients had presented at the Emergency Dept (ED) within the first 8 hours of the sting and scorpion antivenom had been administered because of complaints of local oedema, hematoma, redness, pain, sensitivity and local numbness in some cases. Admission to ICU was recommended as the local symptoms did not recede during the follow-up. For the patients admitted to ICU with local symptoms, treatment was started of antibiotics, non-steroid anti-inflammatory drugs (NSAID), low molecular weight heparin (LMWH) and IV hydration. Only 2 patients were followed up for more than 2 days in ICU. These were a male aged 54 years with affected right lower extremity and a female aged 56 years with affected right upper extremity and in both cases, circulation problems were experienced due to increased oedema starting in the distal section of the extremity. On Doppler USG the development of widespread thrombus as far as the proximal of the stung extremity was seen and supportive treatment was applied with follow-up for a period of 9 and 12 days respectively. No respiratory or cardiac problems were experienced in the continued follow-up in the ward and both patients were discharged from there.

\section{Discussion}

Scorpion poison is a toxin causing local, systemic and neurotoxic effects within the first 24 hours of the sting. While the poison of some species only causes symptoms such as fatigue and aches, with some other species, death may occur within hours. Although this difference can vary according to the species of scorpion, age, size, amount of venom, nutritional characteristics, climate conditions, whether the poison has reached the venous system or tissues, and the patient's age, where the patient has been stung can also make a difference $[4,5]$. The number of stings of the scorpion and that the person is the first to be stung is important in terms of the effect of the amount of toxin [6]. If the poison is injected into the tissue, distribution around the body will occur in 30-60 mins, whereas if injected into the venous system, it will spread around the body in 4-7 mins. Mixing into the blood circulation causes a worsening of symptoms $[7,8]$. Scorpion toxicity usually leads to local reactions and more rarely to systemic symptoms [9].

Pain, increased temperature, oedema and hematoma in the stung area are the local findings that usually occur. Systemically, hypotension or hypertension, respiratory failure, hemolysis, kidney failure and hemorrhagia in various regions may be seen [10]. No systemic findings were observed in any of the patients in the current study, only local symptoms. Neurotoxins, agglutinins, leukocytolysins, coagulins, lecithin and cholesterin are found in scorpion poison [11]. The most potent toxin in scorpion poison is neurotoxin. Scorpion poison provides an extremely strong stimulus to the autonomous nervous system and the pathology is extremely complex [12]. The primary effect of the toxin is sympathetic and parasympathetic postganglionic stimulation. Usually the sympathetic effect is evident [4]. No sympathetic findings were observed in any of the patients in the current study. Neurological findings which develop associated with the toxin emerge in the first day $[13,14]$. No neurological findings were observed in any patient in the current study.

The fall in the $\mathrm{Hb}$ and htc values of the patients on the 1 st and $2^{\text {nd }}$ day is hought to be associated with the intravenous hydration applied from the time of admittance. That no significant difference was found in the 
thrombocyte and RDW values during follow-up of the patients suggested that there was no consumption coagulopathy.

Not all scorpion stings may be poisonous. However, treatment must be planned on the assumption that all scorpion stings cause toxicity. Treatments applied for scorpion stings consist of fluid electrolyte treatment, antibiotics in some cases, tetanus injecton, scorpion antivenom and analgesics [15]. In Turkey, a polyvalent scorpion antiserum is used which is produced in our province obtained from horses stung with the Andractonus crassicauda species scorpion venom. The application of scorpion venom is still a controversial subject. While some authors consider that correct management of the treatment in scorpion poisoning will remove the need for specific antivenom, there are also authors who recommend not administering antivenom [16-18].

In another study, IV antivenom treatment was administered to patients showing only systemic symptoms and these symptoms were determined to recover and in the same study it was reported that 2 patients who were not given antivenom treatment died [19]. In the current study, all the patients were administered antivenom and tetanus injection in the ED before admittance to ICU. Therefore, as there was no group admitted to ICU who had not been administered antivenom, no comparison could be made. However, as systemic complications are not generally seen in this region where there are extremely poisonous scorpions can be considered to be due to the effect of the antivenom prepared for the scorpions specific to this region. One of the significant factors limiting the efficacy of the antivenom treatment is the time from the sting to the application of the antivenom [18].

Application of the antivenom at the correct time and application of the necessary supportive treatment have been shown in previous publications to significantly reduce morbidity and mortality [20, 21]. In the current study, all the cases presented within the first 8 hours, all were administered with antivenom and no systemic symptoms or mortality were seen in any case. Consistent with previous reports in the literature, all of the current study cases presented in the spring or summer months with a sting on one extremity $[22,23]$. All the patients accepted into the ICU in this study were patients who presented in spring or summer, had been stung once on an extremity, had presented at ED within the first 8 hours and had been administered with tetanus and antivenom prophylaxis. That no serious systemic complication developed in any of these patients can be considered to be associated with the time of presentation at hospital and that antivenom treatment was applied. Therefore, there can be considered to be a need for ICU admittance only if systemic symptoms develop in the follow-up of patients monitored in ED, and thus there will be no unnecessary loss of workforce in ICU. Scorpion sting is an event which can cause organ dysfunction and can have a mortal course. With a thorough evaluation of patients presenting at the ED with scorpion sting, timely decision-making and the application of correct treatment, morbidity and mortality can be reduced.

There is limitations in our study. The first is that our study is in retrospective style. The recorded data can be limited, our study's sample size.Prospective studies that records all of the information about a patient and its clinic will give more information about ICU acceptations. The second limitation is that there is limited information about 
died people which scorpion stung. More samples will be significant to evaluate this group. However, our study has strong points as to be the first study which evalute scorpion stings in our region.

\section{Conclusion}

It can be recommended that patients with no requirement for the equipment of ICU should not be admitted and patients with local symptoms only should be monitored on the ward.

\section{Acknowledgement}

Authors are sincerely thankful to the support provided by Dr. Ruslan Abdulayev.

\section{References}

1. Karakuş A, Tutanç M, Arıca V, Karcıoğlu M, Tuzcu K, Başarslan F, Duru M. Akrep Sokmalarında Doksazosinin Etkinliği; Çocuk Olgu Sunumu. J Kartal TR 25 (2014): 58-60.

2. Karataş A. Mesobuthus caucasicus (Nordmann, 1840) (Scorpiones: Buthidae) in Turkey, Euscorpius. Occasional Publications in Scorpiology 25 (2005): 1-7.

3. Bernstein JN. Antivenom (scorpion and spider). In: Goldfrank LR, Flomenbaum NE, Lewin NA, Howland MA, Hoffman RS, Nelson LS, editors. Goldfrank's toxicologic emergency. 7th ed. New York: McGrawHill; 2002. p. 1589-91.

4. Gümüş̧tekin M. Çevresel toksinler: Hayvan isırma ve sokmalar». Türkiye Klinikleri Farmakoloji Toksikoloji Özel Sayısı 1 (2003): 53-57.

5. Dökmeci . Toksikoloji zehirlenmelerde tanı ve tedavi. 3. Baskı. Nobel Tıp Kitabevi istanbul, 2001: 621623.

6. Bawaskar HS, Bawaskar PH. Scorpion sting: update. J Assoc Physicians India 60 (2012): 46-55.

7. Cheng D. Scorpion sting. Emedicine instant access to the medicine. Available from: http://www.emedicine.com/med/topic2081.htm. Accessed: January 20, 2004.

8. Doğanay Z, Karatas AD, Baydın A, Bildik F, Aygün D. Akrep antivenom uygulaması her olguda gerekli midir? Olgu sunumu. Türkiye Acil Tip Dergisi 6 (2006): 76- 80.

9. Cupo P, Figueiredo AB, Filho AP, Pintya AO, Tavares JGA, Caligaris F et al. Acute left ventricular dysfunction of severe scorpion envenomation is related to myocardial perfusion disturbance. Int J Cardiol 116 (2007): 98-106.

10. Kaya E, Çıkım K, Kuku Đ, Şavlı H ve ark. Yılan ve akrep sokmalarında hastalarda görülen hematolojik bozukluklar ve klinik seyir. Turkish Journal of Heamatology 19 (2002): 3.

11. A, Şahan M, Kömür M, Yılmaz HL, Dinçer Yıldızbaş D. Akrep sokması sonucu kalp yetmezliği ve priapizm. Karakuş Tıp Araştırmaları Dergisi 10 (2012): 72-74.

12. Ellenhorn MJ. Envenomations-bites and stings. In: Ellenhorn MJ, Schonwald S, Ordog G, Wasserberger J, editors. Ellenhorn's medical toxicology. 2nd ed. Baltimore: Williams \& Wilkins Publishing; 1997. p. 173798 
13. Chen H, Lu S, Leipold E, Gordon D et all. Differential sensitivity of sodium channels from the central and peripheral nervous system to the scorpion toxins Lqh-2 and Lqh-3. European Journal of Neuroscience 16 (2002): 767-770.

14. Marshall DL, Vatanpour H, Harvey AL, Boyot P et all. Neuromuscular effects of some potassium chanel blocking toxins from the venom of the scorpion leiurus quinquestriatus hebreus. Toxicon 32 (1994):14331443.

15. Kurtoğlu S. Zehirlenmeler, teşhis ve tedavi. Kayseri: Erciyes Üniversitesi Yayınları, 1992.

16. Gueron M, Sofer S. The role of intensivist in the treatment of the cardiovascular manifestations of scorpion envenomation. Toxicon 32 (1994): 1027-1029.

17. Sofer S, Shahak E, Gueron M. Scorpion envenomation and antivenom therapy. J Pediatr 124 (1994): 973938.

18. Abroug F, ElAtrous S, Nouira S, Haguiga H, Touzi N, Bouchoucha S. Serotherapy in scorpion envenomation: a randomised controlled trial. Lancet 354 (1999): 906-909.

19. Dudin AA, Rambaud-Cousson A, Thalji A, Juabeh II, Abu-Libdeh B. Scorpion sting in children in the Jerusalemarea: A review of 54 cases. Ann Trop Paediatr 11 (1991): 217-223.

20. Adıgüzel S, Özkan Ö, İnceoğlu B: Epidemiological and clinical characteristics in Sanliurfa, Turkey. Toxicon 49 (2007): 875-880.

21. Yılmaz F, Arslan ED, Demir A, Kavalci C, Durdu T, Yılmaz MS, Yel C, Akbulut S. Epidemiologic and clinical characteristics and outcomes of scorpion sting in the southeastern region of Turkey. Ulus Travma Acil Cerrahi Derg 19 (2013): 417-422.

22. Silva RLM, Andrea M, Amorim TK. Envenomation by Tityus stigmurus (Scorpiones: Buthidae) in Bahia, Brazil. Rev Soc Bras Med Trop 33 (2000): 239-245.

23. Al-Sadoon MK, Jarrar BM. Epidemiological study of scorpion stings in Saudi Arabia between 1993 and 1997. J Venom Anim Toxins incl Trop Dis 9 (2003): 54-64.

Citation: Ayşe Şahin Tutak, Meral Çeliker, Hüseyin Avni Fındıklı, Bülent Karakaya, Atilla Tutak, Öznur Uluadağ. Should All Scorpion Stings be Followed Up in the Intensive Care Unit?. Archives of Clinical and Biomedical Research 2 (2018): 007-014.

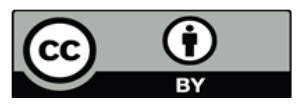

This article is an open access article distributed under the terms and conditions of the Creative Commons Attribution (CC-BY) license 4.0 